\title{
Learning Cycle Assisted by Physics at School Application : Optical Instruments Concept
}

\author{
Fathiah Alatas $^{1}$, Annisa Fitri Komariyah ${ }^{2}$ \\ \{ fathiah.alatas@uinjkt.ac.id ${ }^{1}$, annisafitri.komariah14@uinjkt.ac.id² \\ UIN Syarif Hidayatullah Jakarta ${ }^{1,2}$
}

\begin{abstract}
The purpose of this research is to assess learning outcome and cognitive structure of grade $11^{\text {th }}$ high school students on optical instruments concept. The research aimed to reveal the influence of Learning Cycle assisted by Physics at School Application. This research was quasi-experimental research using Pre- and Posttest Design. Subject of this research was grade XI students of Senior High School Jakarta as many as 70 students. Learning outcome data were collected by test developed by researcher, meanwhile cognitive structure data collected by student worksheet. The result showed that implementation of learning cycle assisted by Physics at School Application can increase students' learning outcome which are knowledge $(\mathrm{C} 1)$, comprehension $(\mathrm{C} 2)$, application (C3) and analysis (C4). And also in the experimental group found that misconception decreased after applied learning cycle assisted by Physics at School Application.
\end{abstract}

Keywords: Learning Cycle, Physics at School Application, Optic Instruments Concept.

\section{Introduction}

Optic instruments concept is one of the topics interest to students studied for its application in life, unfortunately in this topic students do not realize or they are aware but do not fully understand the concept [1]. Optical instrument concept studied include tools used in life such as magnifying glass, cameras, microscope and telescope [2]. Students learn how magnifying glass, camera, microscope and telescope work in form image of the object [3]. In fact, in the class students have difficulty in understanding this chapter [4]. Especially if the students still do not understand the concept of congruency, angular relationship and geometric optics concepts learned in junior high school level [5]. As a result, students finally memorize formulas of magnification different from each tools. This causes students to be passive in the learning process and student learning outcomes become incompatible expected of teachers, so that this chapter requires a complex understanding.

Physics meaningful learning must go through a learning experience that enables students to formulate their own concepts. Students often formulate a wrong conception of acquisition concept [6]. According to Flavell and Miller students build concept by obtaining information from the learning experience, and to organize and transform[7]. Learning outcomes described by the cognitive structure. During the learning process of cognitive structure is divided into three categories: understanding, misconceptions and did not understand [8].

Characteristics optical instrument, the students are expected to connect the concepts of physics studied with the phenomena that exist in everyday life by way of constructing their 
own knowledge [9]. One of study model capable in facilitating students to construct knowledge through related phenomena is learning cycle [10]. This is in line with the statement of Bybee that is one of the student-centered learning model phases ; students can conduct investigations, provide an explanation, apply the concept in a new situation and also evaluate the learning cycle [11].

The phases of learning cycle models continue to evolve over three phases, five phases (5E) then become seven phases (7E) [12]. Learning cycle with three phases proposed by Karplus and Their in 1967: exploration, concept and Application [13]. The next learning cycle developed into 5 phases is often called the $5 \mathrm{E}$ learning cycle. These steps are engagement, exploration, explanation, elaboration, and evaluation [14]. In 2003 Arthur Eisenkraft developed it to become 7E learning cycle. The phase 7E learning cycle means; elicit, engage, explore, explain, elaborate, evaluate and extend [15]. Recent research conducted by Ridwan and Rahmawati modified the process of phase model of $8 \mathrm{E}$ learning cycle, which stands for engage, explore, E-Search, elaborate, exchange, extend, evaluate and explain [16]. The significant difference between the $8 \mathrm{E}$ learning cycle and $7 \mathrm{E}$ learning cycle contained in the $\mathrm{E}$ search phase. Based on the development of the learning model cycle that at first there are only 3 -phases and continue to grow until 8 phases, indicating that the importance of learning elements. Phases of the $8 \mathrm{E}$ learning cycle organized in such a way that students can play an active role in learning activities such as demonstrations or experiments.

Innovation is the use of technology in learning Android smartphone to do a demonstration or experiment, in order to minimize time and effort [16]. Using smartphones in learning physics rated very important role in the understanding of the students because students can build understanding through simulation and evaluation and they can repeat every time [17]. In addition, the use of simulation as a learning tool is expected to help students in solving problems in real life [18]. Therefore it is necessary to do research on the application used of android-based virtual laboratory [19]. For Android users there is an application that consist of a good physics content that is Physics at School. The application can be downloaded for free in the Play Store. Physics at School presents the simulation of physics concepts ranging from mechanics, electricity, magnetism, relativity, optics and many more. In Optical instrument, students have difficulty in understanding the form of an image on a magnifiying glass, microscopes and telescopes. Using Physics at School application in teaching instruments optics can be a solution to overcome the students' difficulties

\section{Research Methods}

The method used was a quasi-experimental design [20]. The population of this study were all students of class XI Senior High School Jakarta in academic year 2018/2019. The technique sampling used was purposive It was decided that XI MIA 1 as the control group applied the conventional learning and XI MIA 2 as the experimental group using $8 \mathrm{E}$ learning cycle assisted by Physics at School. The independent variable in this research was $8 \mathrm{E}$ learning cycle assisted by Physics at School application. The dependent variable is learning outcome of cognitive structure in the topic of optical instruments concept

Methods of data collection were tests and observation. The test method aims to obtain data on student learning outcomes of optical instrument concept. Method of observation in this study aims to obtain data on students' attitudes during the learning with 8E-learning model assisted by Physics at School application. 
This study has three phases procedure that include: (1) the preparation phase consists of, covering the literature to formulate the problem, problem formulation research, sampling, preparation of lesson plans, worksheets manufacture, test instruments and nontes. After the researchers tested the feasibility of the instrument to some experts and students who are learning the topic optical instrument. Eligible instruments will be tested to class XI to determine the experimental class and control class. (2) The data acquisition phase is planned to start by giving a pretest to determine the initial ability of students and at the same time establish an experimental class and control class,when learning observer filling the observation sheet. the posttest was done to measure student learning outcomes. (3) in the phase of analysis, researchers and analysts analyzed the data which have been obtained previously, then tested the hypothesis until the conclusion of the study.

Analysis of the early phases of this research are used to determine the control and experimental groups by giving an average pretest score of the highest pretest to a control group while the average score of the lowest pretest into the experimental group. Data analysis is the final phase of the test results of student learning outcomes in experimental and control groups before and after treatment using a different learning models. Before testing the hypothesis, the first step was to perform the prerequisite test that is test of normality and homogeneity, while to know the learning outcome after learning calculation was used NGain formula

\section{Results and Discussion}

The results were obtained in the form of data from pretest and posttest, $\mathrm{N}$-gain of the experimental group and the control group and the data on the observation of students during the learning. Data pretest and posttest results are presented in the form of a score. Before getting treatment, samples are given a pretest to determine the starting conditions. The results of pre-test showed that the class XI MIA 1 got an average score of 7.2, while the class XI MIA 2 reached an average score of 5.7 out of a total score of 23, thus XI MIA 1 to a control group that applied conventional learning models and XI MIA 2 into the experimental group applied learning model 8E-aided learning cycle Physics at School application. Conditions initial ability of students to each cognitive domain are superior to the control group experimental group. In the cognitive domain C1 (knowledge) C2 (comprehension), C3 (application) and $\mathrm{C} 4$ (analyze) are $\mathrm{t}$ in the average score of significant difference between the control group and the experimental group, while in the cognitive domains $\mathrm{C} 1$ (remember) has differences in the average score of the control group and the experimental only 0.07 adrift. The low score of students qualitatively and quantitatively is due to passive learning, because students are not interested to participate in learning.

The result of the ability of the student's final after application of different learning models is the experimental group, it was obtained a score that is superior compared to the control group. The average score of 18.28 posttest experimental group and the control group of maximum score 23.00 13.80. Lowest cognitive domain that is $\mathrm{C} 3$ the experimental group with a percentage of $66 \%$, while the highest cognitive $\mathrm{C} 1$ with a percentage of $95 \%$. In the control group, namely the lowest was cognitive $\mathrm{C} 2$, while the highest was cognitive $\mathrm{C} 1$. Increased $\mathrm{N}$ Gain learning outcomes of students in the control group reached 0.38 was in the medium 
category, while the experimental group N-Gain scores of 0.72 to a high category. Summary of pre-test and post-test scores are in Table 1 below.

Table 1. Table Summary of pretest and posttest scores Data Control Group and Experimental Group

\begin{tabular}{lcccc}
\hline Statistics & \multicolumn{2}{c}{ Pretest } & \multicolumn{2}{c}{ Posttest } \\
& Control & Experiment & Control & Experiment \\
\hline Average & 7.2 & 5.7 & 13.80 & 18.28 \\
\hline $\begin{array}{l}\text { The } \\
\text { minimum } \\
\text { score }\end{array}$ & 2 & 2 & 8 & 12 \\
\hline $\begin{array}{l}\text { The } \\
\text { maximum } \\
\text { score }\end{array}$ & 11 & 10 & 19 & 22 \\
\hline $\begin{array}{l}\text { median } \\
\text { modus }\end{array}$ & 8 & 6 & 15 & 19 \\
\hline $\begin{array}{l}\text { standard } \\
\text { deviation }\end{array}$ & 2.5 & 1.9 & 7.3 & 2.60 \\
\hline
\end{tabular}

The results of the test prerequisite posttest control group and the experimental distribution data were not normal and homogeneous, then test the hypothesis by using the Mann-Whitney $\mathrm{U}$ test results of the hypothesis is that the alternative hypothesis accepted. The alternate hypothesis states that the experimental group had an average of higher learning outcomes than the control group. This indicates that the implementation 8E learning cycle assisted by Physics at School application effects on student learning outcomes in optical instrument. The statement is in line with research conducted by Elsa Mardika and Waskita Darmiyanti, The study found that the application of the $8 \mathrm{E}$ learning cycle help students understand the concepts so that the level of misconceptions in students to be decreased [7]. In addition, research conducted by Ugyen Dorji, Niwat Srisawasdi, and Patcharin Panjaburee stated that the application of the learning model learning cycle and application Education Computer Game in learning electrical energy can improve learning outcomes and student awareness of the importance of electrical energy [21].

$8 \mathrm{E}$ learning cycle is a student centered learning, so that learning effort students to be able to understand the concepts learning through the learning experience gained at each phase of learning. The learning phase of $8 \mathrm{E}$ learning cycle includes eight first phases are to engage, at this phase the students were given a case study related to the concepts learned. In the explore phase, which at this phase the students gain knowledge helped by the application of Physics at School, this application helps students understand abstract concepts, such as the formation image on optical instrument. The next phase is to e-search, where students find the source references concepts learned through the internet or print book.

The next phase is elaborate, integrating the knowledge gained from the explorer and esearch. The fourth phase is to exchange, at this phase the students conduct a group discussion on the results of the elaborate phase. Next phase extend, at this phase students were given exercises in the form of an extension of concepts learned. Evaluate is seventh phase, at this phase the students were given the opportunity to ask questions and discuss with the teacher to confirm the knowledge obtained in the previous phase. The last phase is to explain or eighth phase, at this phase, the students presented the results in accordance with the answers they 
wrote in the student worksheet, at this phase the students are given exercises in the form of an extension of concepts learned.

This study was conducted during two meetings, the first meeting to discuss the sub topics eye, a camera and a magnifying glass, while the second meeting to discuss the topic sub microscopes and telescope. It is important to know how students construct knowledge for the application of the 8E learning cycle assisted by Physics at School application. Based on the learning phase learning cycle models $8 \mathrm{E}$, understanding the students appeared on phase engage, explore, elaborate, and extend. Student understanding can be analyzed through answers on student worksheet.

Based on the first meeting of the sub topics eye, a camera and a magnifying glass, the emergence of students' understanding of each phase of engage, explore, elaborate, and extend. Phase engage, teachers test students' comprehension by asking questions related concepts learned. Phase engage students' understanding of optical instrument are quite varied some students considered still do not understand or misconceptions. Phase explore, students construct knowledge using the application Physics at School. In the elaborate phase, the students' understanding more or less the same as in the phase more fully explore only due to the e-search phase students can search for related reference. Next phase is extend at this phase students were given about the concepts related to increasing student understanding in the following Figure 1 and 2.

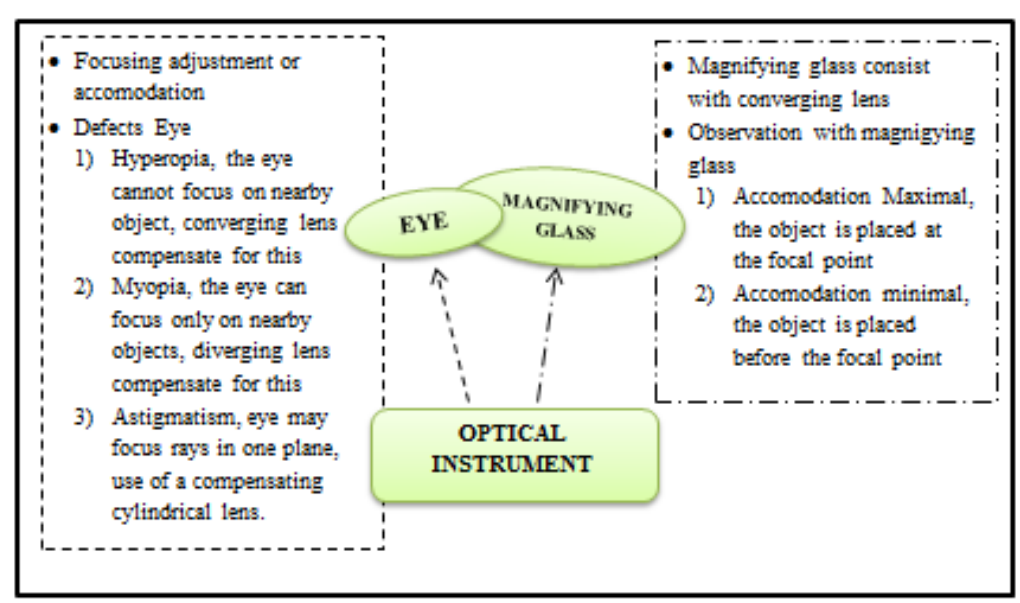

Fig. 1. Essensial Topics for Engage and Explore Phase 


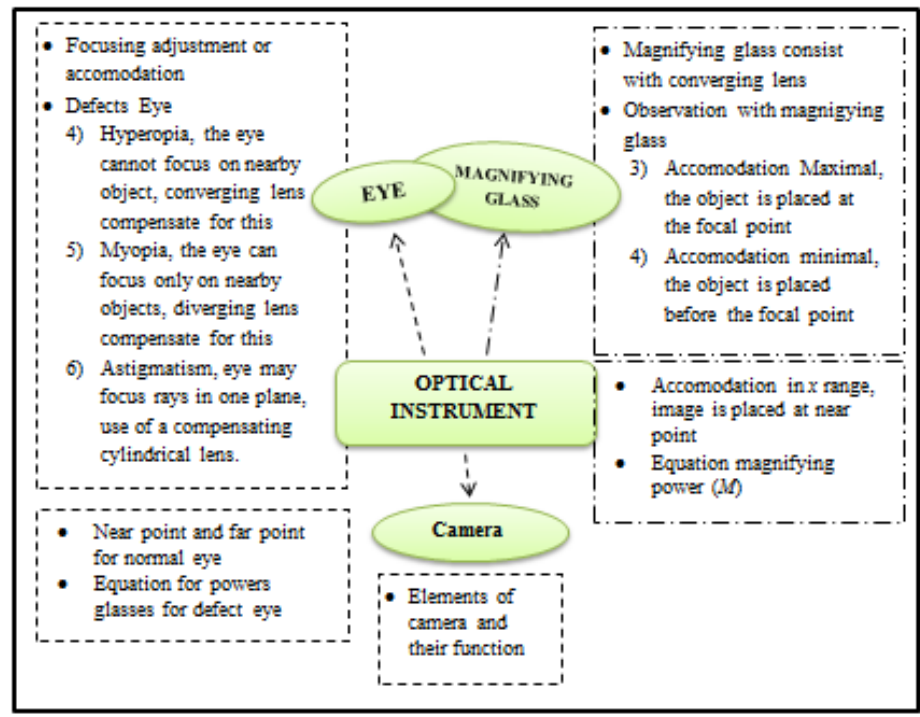

Fig. 2. Essensial Topics for Elaborate and Extend

Based on results of student worksheets, it was found that some students had misconceptions about differences virtual and real image. At the student worksheet engage precisely at the phase of writing:

"Observations using loops produce a real image, erect and enlarged"

(Group 2 and 3, the student worksheet dated 26 April 2019)

Answers to some students on phase engage the student worksheet shows that students do not understand the difference virtual and real image. Image of an object is to be virtual in the event of an extension of the special rays. Students answer after making observations using the application Physics at School shown in Figure 3.

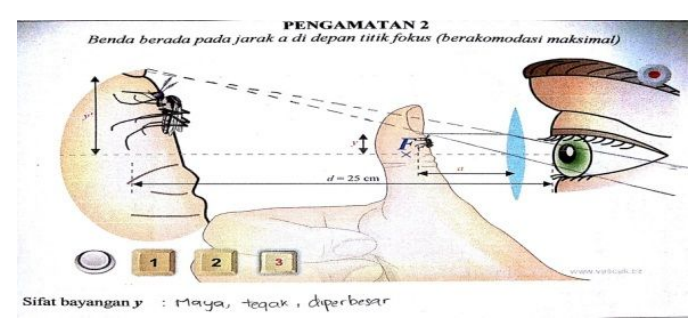

Fig. 3. Students Answer After Learning

Seen that had not found anymore of misconceptions of form image in magnifying glass. This shows that the students are able to construct their own understanding of experiential learning as well. Before entering the elaborate phase, students must pass the e-search phase where at this phase students seeking references from various sources to answer questions on worksheets. In the elaborate phase students combine observations from the phase explore and e-search. The results of the analysis of students' answers on worksheets can not be found misconceptions. Neither the extend phase where at this phase students are required to solve 
several problems. Answer at this phase is also not found misconceptions and do not understand.

The second meeting discussed the sub topic microscopes and telescope. Appearing on engage phase students' understanding, explore, elaborate, and extend. Figures $\mathbf{4}$ and $\mathbf{5}$ is a chart of essential topics of sub topic optical instrument namely microscopes and telescope.

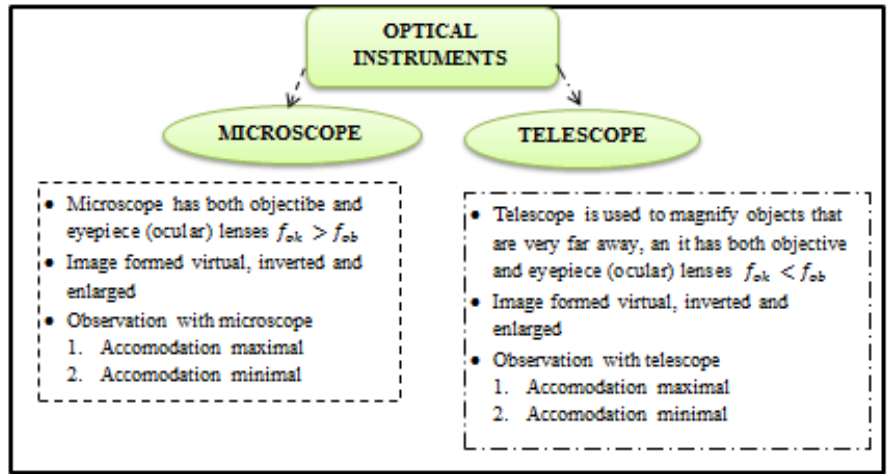

Fig. 4. Essensial Topics for Engage and Explore Phase

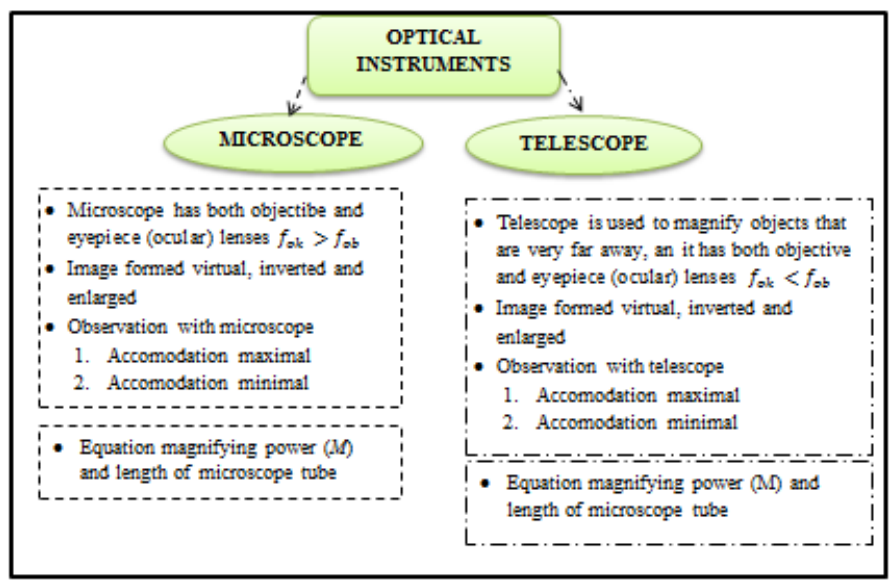

Fig. 5. Essensial Topics for Elaborate and Extend

Students' understanding of the concept of sub microscopes and telescope considered quite good, proven some students answered questions on phase disengagement as in Figure 6. 


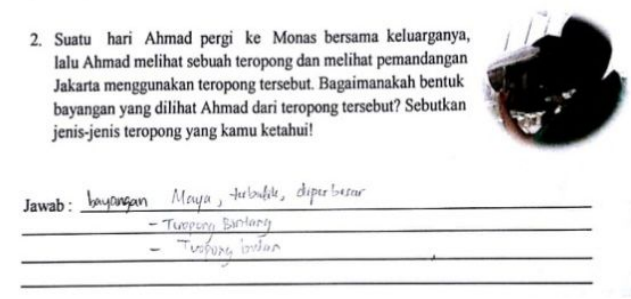

Fig 6 Answers Engage Students on Phase

Based on these answers, the student is considered to have a good grasp on the sub concept microscopes and telescope. This can be caused because students are accustomed to using a microscope in biology lab, so that they understand the part along with the functions of the microscope. Misconception about virtual and real image, also not to be found in this second meeting, in answer student worksheets evidenced in Figure 7 below.

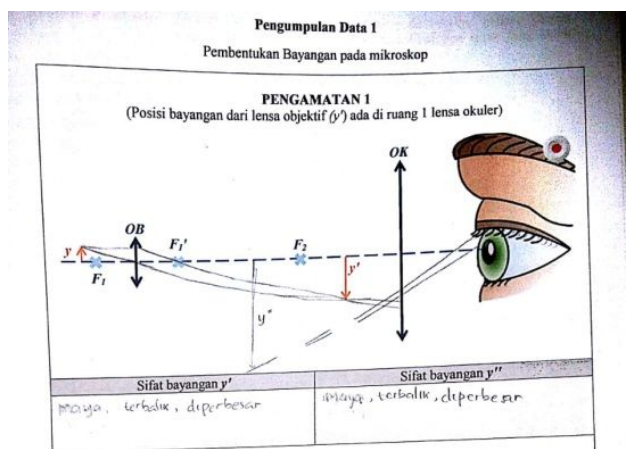

Fig.7. Students Answer on Phase Explore

Phase elaborate and extend in the second meeting, there was also found misconceptions and do not understand. At this second meeting, the students became accustomed to learning to use the model of learning cycle. It is also evident from the observation time of learning which states that during learning, especially at the phase of disengagement and e-search students were able to use the sense and the facts relevant to the percentage $61 \%$ category enough. Meanwhile, on phase as much as $61 \%$ of the students explore noted the observations through the application of Physics at School in student worksheets with enough categories. On phase elaborate and exchange as much as $57 \%$ of students had a discussion related to the observations made in the previous phase. Meanwhile, as many as $63 \%$ of students participate resolve problems found in students' worksheets. During learning, especially at the phase as much as $47 \%$ Evaluate students ask questions to teachers, so students can evaluate his thoughts through dialogue with the teacher. On phase explain as much as $57 \%$ of students presented the results of his observations properly. Overall, the results of observations of students in obtaining the average percentage of $57.5 \%$ to the category enough. 


\section{CONCLUSION}

Based on the results of the study, data analysis and discussion can be concluded that there are significant 8E-assisted learning cycle model of application Physics at School on student learning outcomes in topic optical instrument. The experimental group was applied to the model-assisted learning cycle applications $8 \mathrm{E}$ Physics at School has an average test score of 18.28 with $0.72 \mathrm{~N}$-gain high category, while the control group who applied conventional study had an average test score of 13.80 with $\mathrm{N} 0.38$-gain medium category. The results of observations of students in the experimental group categorized enough (57.5\%).

\section{References}

[1] I. M. Astra and F. Saputra, "The Development of a Physics Knowledge Enrichment Book 'optical Instrument Equipped with Augmented Reality' to Improve Students' Learning Outcomes," J. Phys. Conf. Ser., vol. 1013, no. 1, pp. 1-8, 2018.

[2] Parno, L. Yuliati, and B. Q. A. Ni'Mah, "The influence of PBL-STEM on students' problem-solving skills in the topic of optical instruments," J. Phys. Conf. Ser., vol. 1171, no. 1, 2019.

[3] W. Wirda, A. G. Haji, and I. Khaldun, "Penerapan Pembelajaran Model Problem Based Learning (Pbl) Untuk Meningkatkan Keterampilan Proses Sains Dan Motivasi Belajar Siswa Pada Materi Alat-Alat Optik,” J. Pendidik. Sains Indones., vol. 3, no. 2, pp. 131-142, 2015.

[4] A. Widiyatmoko and K. Shimizu, "Literature Review of Factors Contributing to Students' Misconceptions in Light and Optical Instruments," Int. J. Environ. Sci. Educ., vol. 13, no. 10, pp. 853-863, 2018.

[5] L. Kurniawati, N. S. Aminah, and A. Marzuki, "Assessing scientific literacy on optics among high school students in Kudus," J. Phys. Conf. Ser., vol. 1170, no. 1, 2019.

[6] A. Sutanto, "Interaksi Model Pembelajaran ," Media Akad., vol. 25, no. 2, pp. 183202, 2010.

[7] E. Mahardika, N. Nurbaity, A. Ridwan, and Y. Rahmawati, "Analisis Struktur Kognitif Siswa dengan Metode Flowmap dalam Materi Asam Basa Menggunakan Model Learning Cycle 8E," EduChemia (Jurnal Kim. dan Pendidikan), vol. 3, no. 1, pp. 51-65, 2018.

[8] A. R. HAkim and M. B. Harahap, "p-ISSN 2252-732X e-ISSN 2301-7651," $J$. Pendidik. Fis., vol. 2, no. 1, pp. 34-42, 2013.

[9] O. A. Nanda and I. Wilujeng, "The Effectiveness of Android-assisted Optical Devices Learning to Improve Students' Conceptual Understanding," J. Penelit. dan Pembelajaran IPA, vol. 4, no. 2, p. 105, 2018.

[10] N. Balta and H. Sarac, "The Effect of 7E Learning Cycle on Learning in Science Teaching: A meta-Analysis Study," Eur. J. Educ. Res., vol. 5, no. 2, pp. 61-72, 2016.

[11] I. Wicaksono, B. Jatmiko, and T. Prastowo, "Pengembangan Perangkat Pembelajaran Fisika Model Learning Cycle 5E Untuk Meningkatkan Pemahaman Konsep Siswa Pada Materi Fluida Statis," J. Penelit. Pendidik. Sains Pascasarj. Univ. Negeri 
Surabaya, vol. 4, no. 2, pp. 518-524, 2015.

[12] A. Eisenkraft, "Expanding the 5E model," Sci. Teach. -Washington-, vol. 70, no. 6, pp. 56-59, 2003.

[13] M. Wilder and P. Shuttleworth, "Cell Inquiry: A 5e Learning Cycle Lesson," Sci. Act. Classr. Proj. Curric. Ideas, vol. 41, no. 4, pp. 37-43, 2005.

[14] T. C. Liu, H. Peng, W. H. Wu, and M. S. Lin, "The effects of mobile natural-science learning based on the 5E learning cycle: A case study," Educ. Technol. Soc., vol. 12, no. 4, pp. 344-358, 2009.

[15] S. Sornsakda, P. Suksringarm, and A. Singseewo, "Effect of Learning Environmental Education Using the 7E-Learning Cycle metacognitive Techniques and the Teacher's Handbook approches on Learning Achievement, Integrated Science Process Skills and Critical Thinking of Mathayomsukaa 5 students with Diverent," Pakistan J. Soc. Sci., vol. 6, no. 5, pp. 297-303, 2009.

[16] W. Darmiyanti, Y. Rahmawati, F. Kurniadewi, and A. Ridwan, "Analisis Model Mental Siswa Dalam Penerapan Model Pembelajaran Learning Cycle 8E Pada Materi Hidrolisis Garam," JRPK J. Ris. Pendidik. Kim., vol. 7, no. 1, pp. 38-51, 2017.

[17] M. A. González et al., "Teaching and learning physics with smartphones," Blended Learn. Concepts, Methodol. Tools, Appl., vol. 4, no. March 2016, pp. 866-885, 2016.

[18] J. Ahn, "Application of the Experiential Learning Cycle," E-Learning, vol. 5, no. 2, pp. 146-156, 2008.

[19] F. S. Arista and H. Kuswanto, "Virtual physics laboratory application based on the android smartphone to improve learning independence and conceptual understanding," Int. J. Instr., vol. 11, no. 1, pp. 1-16, 2018.

[20] H. White and S. Sabarwal, Quasi-Experimental Design and Methods, no. 8. 2014.

[21] U. Dorji, P. Panjaburee, and N. Srisawasdi, "A learning cycle approach to developing educational computer game for improving students' learning and awareness in electric energy consumption and conservation," Educ. Technol. Soc., vol. 18, no. 1, pp. 91$105,2015$. 